\title{
Toplumsal Değişim İle Yaratıcı Drama İlişkisi*
}

\author{
Coşkun San**
}

$\ddot{O}$ zet

Çağdaş Drama Derneği üyeleriyle yaratıcı drama liderlerine yönelik olarak yapılan bu konuşmada, özellikle değişim, dönüşüm ve başkalaşım kavramlarl ve değişim-dönüşüm ile sekülerleşme ilişkisi üzerinde durulmuştur. Ayrıca yaratıcı dramanın başkalaşım sürecinde nasıl yaşamsal bir rol oynayabileceği dile getirilmiş ve yaratıcı drama yönteminin de özgürlükler, demokrasi benzeri kavramlar gibi kötüye kullanılabileceğine değinilmiştir.

Anahtar Sözcükler: Yaratıcı drama, değişim, dönüşüm,başkalaşım, toplumsal değişim

\begin{abstract}
In this speech for Contemporaray Drama Association members and drama leaders, the concepts of change, transformation, and metamorphism, and the link among the concepts of changetransformation, and secularization were highly emphasized. Besides, the vital role of creative drama on metamorphic process and the possibility of using drama method such as democracy and freedom in an inappropriate ways were mentioned.
\end{abstract}

Key Words:Creative drama, change, transformation, metamorphism, and social change

Eğer yaratıcı drama ya da eğitimde drama bireyin kendini, buradan çıkarak yakın ve uzak toplumsal çevresini tanıma, özgüvenini geliştirme, daha özgür ve demokratik bir kişiliğe ulaşmasını sağlama gibi amaçlara yönelik bir eğitim pratiği ise toplumsal değişimleri de izlemek ve kendini yeni koşullara uyarlamak zorundadır. Bu gerek yerine getirilmezse, dramanın ne yaratıcı ne de eğitsel işlevini gerçekleştirmesi mümkün olabilir.

Ne ki, en genel anlamında toplumsal değişimin türleri, niteliği ve hangi tarihsel koşullarda oluştuğu bilimsel bağlamda gerçeğe uygun bir biçimde okunamıyor ya da bilinemiyorsa, söz konusu uyarlamanın başarılı olması da beklenemez.

\section{1-Toplumsal değişim ve türleri:}

Tarihsel akış içinde toplumların kimi zaman çok yavaş kimi zamansa daha hızlı bir biçimde değiştikleri, neredeyse doğa yasası niteliğinde bir gerçektir (San, 1985, s.206). Değişim, evrimsel ve/veya devrimsel yollardan geçerek ortaya çıkar ki, eğer toplumdaki değerler düzeneği köklü farklılıklara uğramamışsa, bu sürece yalnızca DEĞİşì adı verilir. Buna karşılık toplumsal değerlerde

* 17 Nisan 2010 tarihli konferans sunusudur.

** Prof. Dr. A.Ü.SBF, Emekli Öğretim Üyesi 
kimi temel farklılıklar ortaya çıkmışsa, bu süreç artık DÖNÜŞÜM adını alır. Ancak her iki durumda da, varolan toplumsal değerlere tümüyle yabancılaştırılmak, köklerinden tümüyle kopartılmak, asla söz konusu değildir.

Geçmişini yadsımak, değerlerine yabancılaşmak ve başka toplum biçimlerine özlem duyarak, onları açık ya da kapalı bir biçimde gerçekleştirmek isteniyorsa, bu artık bir toplumsal değisim ya da dönüsüm değil, sözcügüun gerçek anlamında bir BAŞKALAŞIM'dır. Kafka'nın ünlü öyküsünün almanca adı değişim ya da dönüşüm (Aenderung) değil, başkalaşım (Verwandlung-Metamorphose)'dır. Daha açık bir deyişle, kendi köklerinden tümüyle koparak başka bir “şey” olmaya çalışmaktır.

\section{2-Toplumsal değişim ve dönüşüm ile yenileşme ilişkisi:}

Toplumbilim değişim ve dönüşümü ileri-geri, iyi-kötü gibi değer yargısı içeren kavramlarla nitelendirmemeye özen gösterir. Ancak başka sözcüklerle de olsa, değişim ve dönüşümün hangi yönde olduğunu, özellikle de bu sürecin bir başkalaşım niteliği taşıyıp taşımadığını saptamaya çalışır.

Değişim ve dönüşüm oluşturan bir süreçten beklenen, bu yeni durumun daha geleceğe yönelik bir düzeni ortaya çıkarmasıdır. Oysa uzak ve yakın tarihteki olaylar incelendiğinde, değişim ve dönüşümlerin her zaman YENİİK getirmediği, kimi zaman ESKİ değerlerin hortlatılmaya çalış1ldığı görülebilir. Söz gelimi ortaçağ genellikle bu biçimde anılır. İran devriminin de bir yenileşme çabası olduğu, en azından çok tartışmalıdır.

Öyleyse her değişim ve özellikle de dönüşüm değer yargıları açısından bakıldığında, özlenen ve beklenen bir gelecek hedefine yönelik olmayabilir. Bu durumun saptanmasının yașamsal önem taşıdığg, hiçbir zaman unutulmamalıdır.

\section{3-Laikleşme-sekülerleşme kavram çifti açısından değişim ve özellikle de dönüşüm:}

Laikleşme, kabaca dinin devlete, devletin de dine karışmaması (San ve Bozkurt, 1988, s.157). sekülerleşme (dünyasallaşma) ise, dinin bilime, ekonomiye, siyasete kısacası toplumsal yaşama yön vermemesi şeklinde tanımlanır (San, 1990, s. 194) Her ne kadar, laikleşme devrimsel bir dönüşüm, sekülerleşme ise evrimsel bir toplumsal değişim sonucunda ortaya çıkarsa da bu iki süreç tarihsel akış içerisine biri diğerini önceleyen, böylece birbirini karşılıklı olarak etkileyen bir nitelik gösterir. $\mathrm{Bu}$ nedenle, laikleşme ve sekülerleşme epistemolojik anlamda bir kavram çifti oluştururlar.

Tüm toplumsal yapının dinlerin sultası altında bulunduğu dönemlerde, her türlü toplumsal değişim ve özellikle de dönüşümün, şiddete dayalı bir biçimde önlenmek istendiğinin en çarpıcı kanıtını, ortaçağdaki gelişmeler oluşturur. Rönesans, akılcılığın ve bilimin dinsel prangaların kırılmasına için, yüzlerce yıl yürüttüğü bir savaşımın adıdır. Akılcılığın ve bilimin “yeniden doğması” ise, ancak yüzlerce yıl süren (30 ve 100 yıl savaşları) reform hareketlerinden ve siyasal yenileşmelerden sonra olanaklı hale gelebilmiş, böylece uzun bir süreçten sonra dünya aydınlığa kavuşabilmiştir.

Aklın ve bilimin dinsel dogmaların boyunduruğu altından kurtarılmasının, 12. yüzyıldan başlatıldığında yaklaşık 600-700 yıl aldı̆̆g, günümüzde bile dinin toplumsal yapının tümüne yeniden egemen kılınmas1 
için savaşım verildiği anımsanırsa, değişim ve dönüşüm açısından laik-seküler bir düzenin yașamsal önemi daha iyi anlaşılacaktır.

Kısacas1, laik ve seküler bir temele oturmayan toplumlarda, değişim, dönüşüm, yenilik, gelişme gibi kavramlar, içi boşaltılmış sözcüklerden başka hiçbir anlam taşımazlar.

\section{4-Dönüşüm ile statüko ikilemi:}

Herhangi bir toplumda köklü değişimler sonucunda ortaya çıkan dönüşüm (devrim), kendini geniş halk kitlelerine benimsetebilmek için görece uzun bir zamana gereksinim duyar. Çünkü “...toplumların genellikle alışkanlıkların, daha önceden varolan kuralların, kısacası verili düzenin tutsağı olduğu, toplumsal yaşamı etkileyen her türlü değişikliğe kuşku ile baktıkları ve olabildiğince söz konusu değişikliklere karşı çıkmaya çalıştıkları da bir diğer toplumsal gerçek...”tir (San, 1985, s.206). Demek ki, devrimsel yollardan gerçekleştirilmek istenen dönüşüm bir süreç oluştur ve başarıya ulaşmak için kuşaklar boyu sürdürülmek zorundadır. "Sürekli devrim” kavramlarından anlaşılması gereken, tam da bu gerçektir. Daha açık bir deyişle, devrim yoluyla getirilmek istenen yeni kural ve kurumlarla eskileri arasında, kimi zaman açık çatışmalara varan bir gerilim, kaçınılmaz bir biçimde ortaya çıkar. Söz konusu gizli-açık savaşım sonucunda ise ya yeni eski ya da eski yeni üzerinde egemenlik kurar. Ancak her iki durumda da, hem “yeni” hem de "eski” belli ölçülerde değişikliğe uğramış olurlar.

İşte bu noktada süreç ister yeni eskiyi, ister eski yeniyi yönlendirme aşamasına gelmiş olsun, varlığını koruyabilmek için statükoculuğa yani varolanı korumaya başvurmak zorunda kalır. Bu durum, eski düzeni yeniden canlandırmak isteyenler açısından doğal karşılansa da, dönüşüm savıyla ortaya çıkan devrimciler bakımından bir iç çelişki gibi görülebilir. Söz konusu ikilemi aşabilmenin bilinen tek yolu, temel ilke ve yönelimlerden (strateji) ödün vermeksizin, içinde yaşanılan dönemin koşullarına yanıt verebilecek değişikliklerin (taktik) yapılmasıdır.

\section{5-Toplumsal başkalaşım olanaklı mıdır?}

İster Kafka’nın "Başkalaşım” öyküsü, ister İonescu'nun “Gergedan”1 olsun, bu yapıtlardaki karafatmalaşma ve gergedanlaşma metamorfoz (başkalaşım) simgeleri, bilimsel açıdan olanaklı bulunmayan fantastik ögelerdir. Ne ki, edebi ve dramatik bir gerilim içinde işlenen söz konusu başkalaşım simgeleri, bireyin yakın ve uzak çevresine nasıl yabacılaştırıldığını, kişiliğinin nasıl parçalandığını ve hızla "yok olma” aşamasına ulaştırıldığını, çarpıcı ve öğretici biçimde ortaya koymaktadırlar.

Buradan çıkarak, toplumsal başkalaşımın da toplumbilimsel açıdan olanaklı bulunmadığını, bu söylemin abartılı olduğunu ve daha çok bir uyarı niteliğini taşıdığını saptamak gerekir. Ancak, başkalaşımın bir sosyal ve sosyo-psikolojik bir süreç olduğunun da asla gözden kaçırılmaması gerekir. Bu sürecin sonucunda ise, ya söz konusu uyarı toplumsal güç odaklarınca dikkate alınır, böylece toplumsal değerler tümüyle yok olmaktan kurtulur ya da toplum çok tehlikeli bir değer ve kural yoksunu amorf aşamaya girerek, toplumsal "çözülme" uçurumuna yuvarlanır. 


\section{6-Yaratıcı ya da eğitsel dramanın başkalaşım sürecindeki işlevi ne olabilir?}

Ortada toplumsal değerlere dayalı bir yapı kalmayınca, başka bir deyişle toplumsal çözülme gerçekleşince ya da tek tek etnik, dinsel ve ideolojik kümeleşmelerin belirmesi, bunların çevredeki benzer siyasal birimlere eklenmeleri ya da baskıcı (faşizan) bir iç dinamiğin parçalanmış kümeleri birleştirmek amacıyla eyleme geçmesi sürpriz olmayacaktır.

Böylesine bir aşamaya gelindiğinde yaratıcı ya da eğitsel dramanın artık hiçbir etkisinin söz konusu edilemeyeceği açıktır. Öyleyse dramaya dolayısıyla daha özgür ve demokratik bir düzenin oluşmasına gönül verenlere düşen yaşamsal görev, başkalaşım süreci toplumsal çözülme aşamasına ulaşmadan önce, bireyleri ve toplumsal odakları bu konuda bilgilendirmek yoluyla bilinçlendirmektir. Kavram ve değer kargaşasının bir toplumsal yıkım gibi, insanların üzerine çöktüğü bir zaman diliminde, söz konusu görevlerin yerine getirilmesinin zorluğu ortadır. Ancak bu neredeyse kaotik ortamda, bireylerin kendine sunulacak "rol modelleri”ne, bir kurtarıcı gibi sarılabilecekleri de asla unutulmamalıdır.

\section{7-Yaratıcı drama yönteminin kimi önemli avantajları:}

Salt bilimsel temelli didaktik yaklaşımlardan farklı olarak yaratıcı drama, tasarımsal ve düşlemsel yorumlara olanak sağlar. Böylece içinde yaşanılan gerçeklerden çıkılarak olası gelecekteki özgürlüklere ve demokrasiye, kısacası insanca bir uygar düzene yönelebilecek tehdit ve tehlikeleri uyarıcı ve çarpıcı bir biçimde "canlandırabilmesi" yaratıcı dramanın en etkili yanını oluşturur. Toplumun bütünlüğünü tehdit eden tehlikeleri önceden gören klasik ve çağdaş tiyatro yazarları ile ütopik yapıtlar üreten yazarların (Sözgelimi Orwell ve Huxley gibi.) kitleleri ne denli derinden etkilediklerini anımsamakta yarar vardır. Kısacası yaratıcı ve eğitsel drama, toplumu bilinçlendirme bağlamında çok önemli ve etkili olabilecek özelliklere sahiptir. Yeter ki bu olanaklardan yararlanılsın.

\section{8-Son söz yerine bir kuşku:}

Yaratıcı ve eğitsel drama kötüye kullanılabilir mi?

Özellikle 20. yüzyılda hoşgörü, insan hakları ve demokrasi gibi kavramların kötüye kullanılarak hoşgörünün, insan haklarının ve demokrasinin yok edildiği anımsanırsa, eğitsel bir süreç olan, ayrıca sosyal drama niteliğiyle kitleler üzerinde yönlendirme etkisine sahip olan dramanın da, asıl amacından saptırılarak kötüye kullanılması hiç kuşkusuz olanaklıdır. Yaratıcı drama sürecinin akla, bilime ve ahlaka aykırı bir biçimde hoşgörüyü, insan haklarını ve demokrasiyi yıkacak bir silah olarak başkalaştırılması olasılığı, yaratıcı dramaya gönül verenlerin yalnızca canını acıtmamalı, bu olasılık sürekli akılda tutularak, söz konusu yıkıma karşı gerekli önlemler ivedilikle alınmalıdır. Önlemin, adı üstünde herhangi bir yıkım, hastalık, kötüye kullanma ve benzer durumlar ortaya çıkmadan önce, planlanması ve uygulanması gereken bir tutumlar dizisi olduğu, asla unutulmamalıdır. Bir halk deyişiyle tekerlek kırıldıktan sonra yol göstermenin hiçbir anlam ve yararı yoktur. 


\section{Kaynaklar}

San, C. (1985). Gençlik ve Demokrasi Eğitimi: Gençliğin Eğitimi ve Sorunları, TED Yayınları, Ankara, s. 206

San, C. ve Bozkurt, Ö. (1998). Laik Devlet: Kamu Yönetimi Sözlüğ̈̈, Ankara, s. 157

San, C. (1990). Bir Toplumsal Süreç Olarak Laiklik: Eğitimde Laiklik, Ankara, s. 194 v.d. 